\title{
Service Innovations: What the Managers Believe and What the Customers Say
}

\section{Praneet Randhawa, MiRan Kim \& Ronald F. Cichy}

To cite this article: Praneet Randhawa, MiRan Kim \& Ronald F. Cichy (2016): Service Innovations: What the Managers Believe and What the Customers Say, Journal of Hospitality Marketing \& Management, DOI: $10.1080 / 19368623.2016 .1208598$

To link to this article: http://dx.doi.org/10.1080/19368623.2016.1208598

Accepted author version posted online: 06

Jul 2016.

Published online: 06 Jul 2016.

Submit your article to this journal \lceil

Џ Article views: 3

Q View related articles $\asymp$

View Crossmark data $₫$ 


\title{
Service Innovations: What the Managers Believe and What the
}

\section{Customers Say}

\author{
Praneet Randhawa \\ Merrick School of Business, University of Baltimore, Baltimore, MD \\ MiRan Kim
}

The School of Hospitality Business, Michigan State University, East Lansing, MI Ronald F. Cichy

The School of Hospitality Business, Michigan State University, East Lansing, MI Correspondence: Praneet Randhawa, Merrick School of Business, University of Baltimore Baltimore, MD. E-mail: prandhawa@ubalt.edu

Running Head: Service Innovations in Private Clubs

\begin{abstract}
Service innovation has become a critical organizational capability. It is crucial to understand not only what service innovations service managers introduce but also what service innovations help improve customers' experiences. This study examines the initiatives managers undertake to introduce new services, and to examine whether service innovations improve service experiences for the members. In this study, 300 critical incidents were reported by private club general managers/chief operating officers and 956 were reported by their members in private clubs across the United States. The findings have both theoretical and practical implications. Keywords: Service Innovation, Private Club Industry, Critical Incident Technology, Communication, Hospitality Industry
\end{abstract}




\section{Introduction}

Service innovation has become a critical organizational capability. The importance of service innovation for firms and the worldwide economy is becoming a well-recognized phenomenon. Service industries accounted for approximately $70 \%$ of the U.S. gross domestic product (Kim, Gilmore, \& Jolliff, 2012), and this number is only expected to grow. This study follows, Dotzel, Shanker, and Berry's (2012, p. 259) definition of service innovation as "a new or enhanced intangible offering that involves the firm's performance of a task/activity intended to benefit customers." Because the definition emphasizes both the performance by the firm and the benefits received by the customers, it suggests that learning the perceptions of innovation from both the firm and its customers is critical for understanding its consequences for firm performance (Gatignon \& Xuereb, 1997). Furthermore, both practitioners and academicians argue that innovation strategies can fail if they are not executed effectively (Huang \& O'Brien, 2015; Noble \& Mokwa, 1999; Martinez-Lopez \& Vargar-Sanchez, 2013; Walker, Craig-Lees, Hecker, \& Francis, 2002). Collectively, this suggests that to further our understanding of service innovation it is imperative to understand not only what innovations service managers introduce, but also what innovations improve customers' experiences. In other words, the research intention is to identify service innovation strategies that are helping organizations build the right set of innovation capabilities that also improve their performance.

One effective way to begin to understand and explore whether service innovations are working is by comparing organizations' innovation initiatives with customer service innovation experiences. Therefore, this study is aimed at (1) understanding service managers' perceptions of what innovative initiatives mean, and (2) exploring whether service innovation initiatives have any effect on customer experiences. Since understanding service innovation initiatives is a 
relatively subjective matter given the nature of services, we focused on seeking incidences and experiences by using critical incident technique (CIT). CIT is a technique considered instrumental in advancing the understanding of issues related to service contexts (Gremler, 2004). The sample for this study comes from the private club industry because it is one of the segments of the hospitality industry where academic research on innovation is limited (Barrows, 1995; Barrows \& Ridout, 2010; Barrows \& Walsh, 2002; Ferreira, 1997). Additionally, private clubs form a very unique segment in the hospitality industry. It is a segment where the customerfirm relationship is not only closely knit but also declared between and by both parties by the way of a membership. This unique closeness makes private clubs an ideal setting to explore our research questions. Additionally, private clubs are currently facing several challenges: increased competition among clubs, the decline in membership retention rate, and the changes of membership demographics (e.g, Barrows, 1999; Barrows \& Ridout, 2010; Knutson, 2002; Ferreira and Gustafson, 2014), which makes this segment an ideal sample to study innovation strategies.

Through this project, a total of 1,256 (300 from managers and 956 from their members) incidents were collected from both private club General Managers (GMs) / Chief Operating Officers (COOs) and their members across the United States. This study makes the following three important contributions to the service innovation literature in the hospitality industry. First, it is among the first to understand the perceptions of service innovation from both the managers' and customers' perspectives. This will allow managers and academicians to get a better sense of the different ways service managers initiate service innovations and what customers perceive to be innovative initiatives that improve their overall experience. Second, this study is among the limited studies in the field of hospitality that explore the perception of service innovation from 
the customer's side. Third, this study truly provides a much needed look at how innovation is perceived in the private club industry by both managers and their members. This will act as a catalyst for future empirical research examining the most influential factors that exert the maximum impact on service innovation's success.

\section{Conceptual Background}

\section{Service Innovation}

Service innovation is "the introduction of novel ideas that focus on services that provide new ways of delivering a benefit, new service concepts, or new service business models through continuous operational improvement, technology, investment in employee performance, or management of the customer experience" (Verma, Anderson, Dixon, \& Enz, 2008, \& Enz, 2012, p. 187).

It is important to understand the process for developing and implementing new services. Additionally, the notion of service has shifted from merely acting as a supplement to a product to a value-added element that is actively co-produced with a customer (Lusch, Vargo, \& O'Brien, 2007). For service firms, co-creating with customers can help firms be innovative (Hjalager \& Konu, 2011). Similarly, it is essential to continue to increase researchers' and practitioners' interests in understanding service innovations (Tiger, Stamey, \& Metts, 2010). Despite the increasing interest, the research in the field of service is still not well developed (Essén, 2009; Chase \& Apte, 2007; Maglio \& Spohrer, 2008). Among the limited theory-based studies, service innovation frameworks are viewed as a linear and formal process (Essén, 2009). This approach perceives service innovation as a set of orderly, sequential events and activities, and it emphasizes the significance of good planning, managerial control, and organizational support (Chae, 2012; Essén, 2009). 
Based on Essén's (2009) theory, Chae (2012) developed another model of service innovation by adding unpredictable, local, and emergent characteristics of service innovation. According to this view, a new service emerges from the interaction between economic actors such as service providers and customers, and various resources and contexts (e.g., system integration, administrative support, equipment, technologies) (Chae, 2012; Djellal \& Gallouj, 2005). This view argues that a new service is co-created by the service providers and customers, which emerges due to the unpredictable nature of their interaction and configuration (Chae, 2012; Kristensson, Matthing, \& Johansson, 2008; Vargo \& Lusch, 2004). Therefore, according to this view, service innovation is an evolutionary process that dynamically combines and recombines the resources to meet customers' needs. It is labeled evolving because of the interactive, unpredictable, local, and emergent nature of the interaction among economic actors, resources, and contexts. Thus, in a competitive environment, emergent planning rather than fixed planning can be more valuable for service innovation (Chae, 2012).

Service Innovation Research in the Hospitality Industry

Current service innovation literature in the hospitality industry has mainly focused on understanding the traits of the staffs (Enz \& Siguaw, 2003; Hu, Horng, \& Sun, 2009; Ottenbacher, Gnoth, \& Jones, 2006). For example, Enz (2012) investigated the role of implementing service innovation via using different strategies. The author found that participative staff-centered implementation strategies emerge as the most critical, while other strategies such as implementation by persuasion, leader intervention, and participation are also important.

Apart from the focus of research on the role of staffs in the process of service innovation, there has been limited research that has explored the impact of service innovation from a 
customer perspective. In the limited studies, researchers argue that successful service innovations can result in better customer image, higher customer satisfaction and loyalty, brand awareness, customers' perception of being treated as special, and capability to attract new customers (Enz \& Siguaw, 2003; Ottenbacher \& Gnorth, 2005). They also discussed a number of practices related to service innovations highlighting customer services, food, customer diversity, and green practices.

For example, Enz \& Siguaw (2003) have introduced successful innovation practices toward hotel customers from luxury hotels. The study shows that many luxury hotels have practiced a 24-hour check-in and check-out service at no extra charge. The services for customers to ship luggage in advance and to store luggage at hotels to avoid delays at airports have been implemented. The services of offering napkins inscribed with guests' initials, installing music CDs of guests' preference and mini bars in the room, and introducing comfort food in the in-room dinning menu have been added. In terms of technical services, providing hotel guests with high-speed Internet in all guestrooms and placing printers in the business center have been widely applied. Furthermore, hotel service innovations also incorporate concerns about the protection of the natural environment. Green hotels have initiated environmental programs that provide customers with a variety of educational and instructional materials about recycling, wildlife, and local animals (Enz \& Siguaw, 2003).

Ottenbacher and Gnoth (2005) evaluated hospitality innovation success. They argue that the definition of innovation success should consider three aspects: (1) financial performance such as increases in revenue and profit; (2) indirect customer benefits such as improved image, customer loyalty, and attraction of new customers; and (3) employee benefits such as positive employee feedback and higher competencies of employees. They 
identified nine factors that are essential for hospitality innovation success: market selection, strategic human resources management, employee training, market responsiveness, empowerment, behavior-based evaluation, marketing synergy, employee commitment, and tangible quality. In terms of service innovation specifically, the results show that tangible quality has a significant impact on innovation success including tangible quality of service, service advantage, consistency of service delivery, and innovative technology. Ottenbacher and Gnoth (2005) argued that innovation success is not the result of just one or two innovation activities, but driven by a large array of different service dimensions.

Victorino, Verma, Plaschka, and Dev (2005) examined the impact of service innovation on customers' choices in the hotel and leisure industry. With a sample of 239 business travelers and 691 leisure travelers, they constructed three types of service innovation: hotel type, technology, and customization. First, hotel type assesses whether the hotel is economy, midrange, or upscale. Second, technology measures the availability of Internet access in guestrooms, business centers, and Internet reservation. Third, customization evaluates pet policy, check-in flexibility, room customization, childcare facilities, and in-room kitchen appliances such as coffeemakers, microwaves, and fridges. The results show that hotel type contributes to the most significant portion of customers' choice of a hotel for both business and leisure travelers. In regard to technology, the availability of Internet access has the largest impact on hotel choice for business travelers, while the availability of a business center has the largest impact on hotel choice for leisure travelers. Finally, in terms of service customization, childcare facilities, in-room kitchen appliances, and pet-friendly policies have the largest impact on the customers' hotel choice for both business and leisure travelers. 
Victorino et al. (2005) state that it is crucial for hospitality managers to identify what customer needs are and how the needs can be operationalized in practice. Livens and Moenaert (2000) also emphasized the importance of both internal and external communications during the innovation process. In particular, the external communication mediates customer information to the organization. Communication should be effective to reduce uncertainty of the service innovation and the interactions between customers offer an essential information input during the innovation of service.

However, there is still a lack of customer-oriented and theory-based service innovation studies in the various segments of hospitality organizations. Further, there has been little attention paid to service innovation research in the private club segment.

\section{Private Clubs and Service Innovation}

Private clubs are hospitality organizations where individual members with common interests, experiences, backgrounds, and professions congregate for social and recreational purposes (Perdue \& Koenigsfeld, 2013). Clubs may be categorized as member-owned (typically nonprofit) or as developer-individual-or company owned (typically for profit). The distinctive member-owned clubs honor legacies and traditions, and the private club members who have been accepted by the club are expected to pay monthly dues. Given the members' sense of pride in belonging to a particular club, club members are more attached to their clubs compared to the customers in other segments of the hospitality industry. Part of this attachment is the service of club member-owners in club governance on various committees and the board of directors. This service in volunteer leadership position assists the club with innovation.

Service innovation is about continually creating and/or adding value to the offerings. The service delivery affects how customers perceive the service and how often they use it in the 
future because the delivery involves an interaction between the service provider and its customers (Hertog, 2000; Hubbard \& O’Neill, 2006). Therefore, service innovations are mostly co-produced with the customers (Maglio and Spohrer 2008). Similar service innovation philosophy holds for the private club industry because club members are the driving force for the club's operation. The quality of service is paramount for member satisfaction and loyalty, and the club's long-term profitability (Hubbard \& O’Neill, 2006). Therefore, not only understanding club members' expectations but also co-creating value with them is critical to the overall success of the club.

Today's club members are highly interested in understanding their club's brand image, and they are increasingly pushing their clubs to evolve and be current, while honoring decades, and sometimes centuries, of traditions (White, 2012). Private club managers are hands of the members as they work closely with volunteer members who represent the general members (i.e. the private club's committees and board of directors). The managers exercise their fiduciary responsibilities to establish and improve the private club by maintaining the club's standards and exceeding the club members' expectations. They are also challenged to function as a catalyst for service innovation to provide enhanced value to members.

Managers in private clubs are responsible for circulating information to members about new business practices. Once the club's new service efforts are recognized and understood by most members, the results will be seen as benefiting all. In today's challenging business environment in the private club industry, it is critical to understand how club members act as coproducers of new services to address members' needs and achieve their club's optimal results (Alter, 2008; Chae, 2012; Vargo \& Lusch, 2004). 
Co-creation of value has become a key issue in service innovation because customers' needs, insights, collaborations, and skills are playing a significant role in creating innovative and appropriate services (Chae, 2012; Cova \& Salle, 2008; Spohrer \& Maglio, 2010). In particular, service innovations co-created with members can be an important source of competitive advantage for clubs. The club members feel an integral part of the club by participating actively in producing new services (Chae, 2012; Chesbrough \& Spohrer, 2006). This style of co-creating service innovations can be truly differentiated from competitors in the current club marketplace and fully address members' needs rather than merely deliver a quality service to members (Bettencourt, 2010; Chae, 2012).

Based on the discussion presented above, this study supports Chae's (2012) framework in understanding service innovation as an evolutionary process. In particular, an ongoing interaction between service providers and customers is critical in understanding the true essence of service innovation. Therefore, it is meaningful to examine what service initiatives club managers undertake and what their members consider as innovative initiatives. In the following section, the study method and procedure are described in detail.

\section{Method and Procedure}

In this study, a qualitative research method was applied because many hospitality researchers argue that qualitative research methods in the form of text provide the most valuable information for improving customer experiences (see for example: Groschl, 2012; Hendler \& LaTour, 2008; LaTour, 2007; Pullman, McGuire, Clevel \&, 2005).

Qualitative research involves an inductive approach, which means that themes and categories are identified by interpreting the qualitative data (Elo \& Kyngäs, 2008; Stepchenkova, Kirilenko, \& Morrison, 2009), while quantitative research uses a deductive approach, based on 
the existing framework, and the coding schemes or categories are usually determined a priori (Kim, Cha, Kim, Cichy, \& Tkach, 2016).

A qualitative method can be effective in this study as exploratory research because it can provide rich and elaborate information about club members' perceptions and experiences with the service innovation. Since the qualitative data can be transformed to quantitative data moving from the specific to the general (Insch, Moore, \& Murphy, 1997; Kim et al., 2016), this study will be useful for developing empirical frameworks.

\section{Critical Incident Technique}

CIT is a "procedure, which facilitates the investigation of significant occurrences (events, incidents, processes, or issues) identified by the respondent, the way they are managed, and the outcomes in terms of perceived effects. The objective is to gain understanding of the incident from the perspective of the individual, taking into account cognitive, affective, and behavioral elements." (Chell, 1998, p. 56). It is considered to be a very beneficial technique for understanding emerging topics in services literature (Gremler, 2004). It is particularly considered beneficial to use when the data contain perceptions of both parties involved in the service

exchange (Bitner, Booms \& Terrault, 1990; Bitner, Boom \& Mohr, 1994; Chung \& Hoffman, 1998). According to Gremler (2004), CIT offers other multiple benefits as well, such as understanding service implications in the words of the respondents without any priming or biases. It is considered as a very useful and powerful tool for helping management improve their performance. Many researchers have concluded that CIT is a reliable, valid, and relevant technique for uncovering useful strategies or categories across different raters/judges that have valid and relevant content (Bitner, Booms \& Mohr, 1994; Ericsson \& Simon, 1980; Ronan \& Latham, 1974; White \& Locke, 1981). 


\section{Data Collection}

The data were mainly collected via a web-based questionnaire that was e-mailed to all the members of the Club Managers Association of America (CMAA). The initial email request was accessed by 1,300 managers across the entire CMAA membership base. Three weeks later, a reminder email was sent to those who did not respond initially to the survey. A total of 386 responses were collected from GMs and COOs. After reviewing the responses for completion, 228 responses (with 300 incidents) were retained for the final analysis with a $17.54 \%$ response rate. In our initial survey to the managers, managers were asked if they were interested in participating in our follow-up study with their members. Out of the 386 responses, 120 managers agreed to participate in our follow-up study. In the second phase of the study, our member survey was launched, which asked club members to share service innovations that improved their experiences at their clubs. We received responses from 362 members across 120 clubs (with about 956 incidents).

In terms of the demographics related to $\mathrm{GMs} / \mathrm{COOs}$ responses, $76 \%$ of the managers were at golf/country clubs, $4 \%$ from athletic clubs, $6 \%$ from yacht clubs, $4 \%$ from city clubs, and $10 \%$ were from other types of clubs such as social clubs. In our GM/COO sample, $83 \%$ of the clubs were member-owned; $9 \%$ were corporate owned; and $8 \%$ had other types of ownership. The average length of the relationship held by a club member as reported by the GM/COO is 16 years. The average number of years a GM/COO has been with their individual club is 16 years, and the average number of years of club industry experience was 20 years. As far as the members' demographics are concerned: $91 \%$ of the members belonged to a golf/country club; $5 \%$ were from yacht clubs; and $4 \%$ were from other types of clubs. The average length of the 
membership held by a member was 12 years. Table 1 provides the demographics of the respondents.

\section{Classification of Incidents}

Once the data from both managers and members were collected, the incident classification system of the CIT was used to classify the incidents. The primary aim of classifying these incidents was to answer the main research questions without sacrificing any important details provided in those responses. The classification system established by Bitner, Boom \& Tetreault (1990), consisting of carefully reading of the incidents for more than one time until common themes started to emerge was adopted. Once the common themes were identified, the next phase focused on identifying the exact nature of those themes in order to identify the similarities that allowed for the formation and labeling of specific categories. This repetitive process is carried out until all the incidents are carefully sorted into the right category. In cases where respondents provided more than one piece of information, they were classified into multiple categories.

In this study, the categorization of the incidents is based on the respondents' responses to the questions. Two successive clustering processes by two researchers led to the emergence of major groups for each research question. Once the major groups for each research question were finalized, the next step was delineating categories within each group. This iterative process was carried out until consensus between the two researchers was reached. Both the researchers sorted, read, reread, and categorized all incidents within categories under each group. In the end, multiple groups and subcategories were identified for each research question. Finally, a third researcher, who was not part of initial categorization of incidents, sorted all the incidents. Based 
on the third researcher's categorization, above $90 \%$ of interjudge agreement was achieved for all the groups across all research questions.

\section{Results}

\section{Manager Reported Classification System-Major Groups and Subcategories}

\section{Top Initiatives Undertaken for Introducing New Services/Products}

The initial sorting of incidents for understanding the top initiatives undertaken for introducing new services/products at the clubs resulted in six groups as shown in Exhibit 1.

\section{Group 1. Services.}

Three subcategories emerged within this group: 1) food and beverage services, 2) additional services, and 3) improved services. Many managers reported that by improving food and beverage services $(\mathrm{F} \& \mathrm{~B})$, they are able to attract members to visit more frequently, which has led to revenue generation. Members want variety in their experiences at the club, and many GMs/COOs believe that being creative in their F\&B offerings is a great way to entice members to spend more time at the club. Many clubs have improved their F\& B services by using one of the following strategies: revamping their food menu, creating special theme dinners, encouraging guests to dine at a reasonable price, and improving restaurant aesthetics. Below are quotes from managers that exhibit some of the ways that managers have revamped their F\&B sales.

By providing new and better services, managers are able to increase member participation on otherwise lower member participation days. These new and improved services have not only helped in getting the current members involved in club activities but have also helped in attracting new members to the clubs. The quotes below are examples which illustrate how GMs/COOs have responded: 
"Themed buffet every Friday night; theme changes weekly. Has increased Friday dinner revenue by $38 \%$."

"Partnering with a major chamber organization to offer special membership pricing for top investors. New rate helped the club add a net of nearly 140 members in 18 months."

\section{Group 2. Member Engaging Activities.}

The third group under this category focuses on the shift in the club's strategy. In this group the subcategories are family oriented- and social-activities. Increasingly many clubs are finding themselves at the cross-section of old (with adult children) vs. new (with younger children). Many clubs' memberships are aging, while other clubs know that they too are fast approaching that cross section. Club managers have started slowly shifting their strategic focus for understanding the needs, and developing services/products that are geared toward attracting and retaining younger members. This change in the strategic focus toward the younger generation requires the clubs to be innovative in positioning their club offerings.

"Making the club more family friendly and provide more activities that attract family participation.

"Getting feedback from younger members. Be willing to make changes to original idea to make it better."

From a legacy-enhancing strategy, approaching to families, and particularly children, enhances the odds that those younger members will continue to belong to the club in the future. Members engaging family activities could be thought of as an investment for generations to come. 


\section{Group 3. Communication.}

The two subcategories within this group are: 1) social media, and 2) the use of technology. Managers feel that communication via social media such as Facebook and the use of technology are effective tools for reaching out to their members and increasing members' participation in the club. Communication is also considered as an effective tool for creating public awareness about their club in the community. Furthermore, managers believe that creating a website that communicates the vision and mission of the club is an effective method for communicating about the club to others. Some managers also find the use of different online software an effective way to encourage members to use the club facilities more frequently and hassle-free. Many clubs have seen an increase in member participation after launching online booking and payment options. Here are two quotes by managers that describe their use of technology and social media to improve their club's performance:

"The use of social media, blogs, and mobile services for the website have improved our communication and engagement amongst the membership."

"Use of emails. We send email blasts about every other day with different information regarding food, golf, grounds, and upcoming promotions. It has increased member participation in all areas."

Group 4. Facilities Upgrade.

Managers noted that revitalizing different areas of the club's real estate and assets, such as the golf courses, kitchens, and dining areas have increased member participation. The following quotes describe some of their efforts: 
"Remodeled our pool cabana complex to provide a higher level of food \& bar service. Setting records in utilization and revenue."

"With our renovation, we created four outdoor dining verandas that can seat up to 200 people at any one time, which are full most evenings in the summer."

As the above comments suggest, renovation is helping clubs to attract their current members to use the facilities more frequently by providing the members with higher perceived value in the "newer" facilities.

\section{Group 5. Better Management.}

This group has two subcategories that represent important aspects related to better management. The subcategories are member surveys and staffing. Many club GMs/COOs find that member surveys are a good tool for understanding member needs and wants. Conducting surveys helps clubs to introduce effectively new services that are targeted specifically to meet the expressed needs and wants of their members. Below is a quote that clearly delineates how managers have been able to make effective use of surveys:

"Through a questionnaire to users of the fitness area, we learned of an interest in acupuncture. We initiated a program and generated some extra income for the club."

The last subcategory under this group is staffing. Just like in any other service firm, the staff also plays a key role in improving club's initiatives to be innovative by selecting, orienting, and training the right people. Managers believe that well-trained staff members help in providing better and higher quality service to the members, which helps the club to provide added value to their members. Below are some of the examples that show the importance of staff training: 
"Training the staff to focus on member retention. Positive effect on current members to stay on as members."

"Changing the guard and making key staffing changes that have brought a lot of energy to the club. The new staffs are hungry, work harder and are more receptive to new ideas. In the short-term it is hard to do, but long-term it is in the club's best interest."

Member Reported Classification System-Major Groups and Subcategories Top Innovative Services/Products That Have Improved Member Experiences

The sorting of incidents for understanding the top innovative services and products that have improved club member's experiences resulted in six groups as shown in Exhibit 2. Group 1. Services.

The first group that emerged under the member classification system focused on innovative services. The first subgroup identified under this category is food and beverage services that have improved the overall member experiences at the clubs. Two key themes emerged under this subgroup. The first theme focused on a diverse selection on the menu, which many members reported as an attraction to visit the club more frequently. The second theme under this group was dining options. Club members reported excitement in having multiple theme restaurants as well as reviving old restaurants with new looks. The quotes below are examples of the experiences shared by the members.

"Small plates menu at the clubhouse provided a different dining experience."

"Increasing the variety of dining options."

The second subgroup under the services group was additional service features provided by the club. By receiving new and better services, many members reported an enhancement in 
their club experience. These new and improved services provided members with a feeling of more value for their money. Moreover, some of the services offered in the form of childcare or facilities for handicapped people made the members feel more privileged and generated a better sense of connection with the club. Here are some of the quotes related to this group:

\section{“Babysitting services.”}

"Spa facilities. It is nice not to have to go outside of the club for spa services."

The third group that emerged was associated with friendly and caring staff members. Members reported that attentive and caring staff members, along with a good management who know how to run service operations effectively, have improved their overall experiences at the club. The quotes below clearly delineate the importance of having a good club management team.

"Staff attitude, strong management, and fiscal responsibility of the club."

\section{Group 2. Facility Upgrade.}

The second group focused on the facility upgrade aspects of the club experiences.

Members greatly appreciate the club's initiatives to improve different aspects of the property that not only helped in keeping the club looking up-to-date but also provided more value for money in terms of better facilities. Below are quotes from members that exhibit some of the ways that their clubs have improved their experience.

"Golf course renovation has been completed on all courses."

"Improved and expanded the fitness center."

\section{Group 3. Member Recruitment.}

Two subcategories are in this group that focus on membership flexibility and new member initiatives undertaken by the club. Member recruitment initiatives provided current members the 
opportunity to connect with new members that bring additional revenues to the club and networking for the existing and new members. The more value-added membership options the club offers, the more it is able to attract and retain members.

"New membership fees resulting in more members."

"Increased forms of membership. Benefitted me in that it attracted more members."

Group 4. Strategic Focus on Member Activities.

Members at the club want to be involved and engaged with club activities. One way they feel excited and encouraged to do so is by engaging in more social activities. Many members reported that social activities geared toward youth and family allow members to enjoy and visit the club more frequently. Many members also expressed appreciation for sporting events that allow them to engage with other members.

"My club partners with the United States Tennis Association to bring several outstanding tournaments to our club. I enjoy these both as a volunteer and a spectator."

Group 5. Improved Perks.

In this group, we found four subthemes that pointed to the different incentives that have increased member experiences. Members reported that getting more value for money through member referral or free golf with dining had improved their overall experiences at the club. Additionally, many members reported that a relaxed dress code and informal dining, as well as guest packages. have increased their frequency for visiting the club with family and friends.

"Incentives to try the club at a reduced price with member referrals." 
"Relaxed dress codes for families with younger children and for those who desire comfortable informal dining."

\section{Group 6. Communication.}

In this last group, we found two subgroups that focused on effective communication. The first subgroup pointed to communication via use of technology. Members expressed the ease of using technology for making dinner and golf reservations along with getting club updates through smart phone applications as an added benefit to their overall membership experiences.

"Internet-based reservations for golf, tennis, dining. Faster, more reliable reservations and the ability to track your schedule as well as others."

The other subgroup in this section is related to better communication. Members expressed their desire to stay connected and up-to-date about club activities. They reported that receiving weekly emails and Facebook updates keep them in the loop, and they do not feel that they are missing out on events. The following are some of the comments shared by the members:

"Communication of marketing initiatives."

"Increase email newsflash that keeps me informed almost immediately of traffic conditions, weather or security concerns."

Comparing Manager Reported Initiatives and Member Expectations

In this section, we compare the main groups of responses provided by both the GMs/COOs and club members to get a better sense of the common similarities and differences in their expectations for better and newer experiences. Based on the analysis, the top innovation initiative reported by most GMs/COOs (48\%), as well as members (37.55\%), is improved services. Both managers and members seem to benefit from better food and beverage services besides enjoying some additional service initiatives undertaken by the clubs. The next highest 
rated category reported by managers is member engaging activities $(23 \%)$, while only $13.12 \%$ of the members reported in that category. Likewise, members reported facility upgrade initiatives $(22.45 \%)$ as their second most critical innovation initiative for better experiences, but only $10 \%$ of the GMs/COOs responses included this as a critical innovation initiative. Our results also show that members take note of member recruitment initiatives undertaken by the club. In our sample almost $21 \%$ of the members acknowledged member recruitment initiatives. However, this study did not reveal much acknowledgment from GMs/COOs on using member recruitment as an innovative strategy for increasing member engagement in the club. In light of this comparison, these are the main areas of discrepancy that highlight the mismatch in GMs/COOs focus and members expectations. These are explored in greater depth in the discussion section.

\section{Discussion}

Research on service innovation has been somewhat limited in the club industry. This study was designed to investigate how club managers introduce service innovations and how their members perceive these innovations. While this pilot study utilizes private clubs GM/COOs and club members, the respondents were primarily from the member-owned golf and country club segment. With further study beyond this pilot, results may be generalized to other types of private clubs. Although the results are not generalized to the hospitality industry, there is no question that service businesses, and hospitality businesses in particular, seek to transform the relationship between their organization and the member or guest or customer to one that is less transactional-based, and one that is more loyalty-based through services and innovation that build and strengthen relationships. The findings have both theoretical and practical implications. In the following subsections, the implications are discussed in detail. 
First and foremost, this study is one of the few studies within the hospitality industry context that examines service innovations from both the organization and customer, member, and guest perspectives. The findings of this study offer significant implications for developing service innovation models. In particular, this study extends the existing literature on service innovation, which emphasizes the importance of co-producing to enhance value with service providers and customers. Thus, this study provides a better understanding of by what means service managers initiate service innovation and also in what manner members perceive innovation initiatives.

Members evaluate the quality of service while they are interacting with the staffs who are working in member-contact positions. Therefore, successful service innovation depends on the impact of the transformation process between the staffs and customers (Abramovici \& BancelCharensol, 2004). In particular, the interface between the service provider and its customers is a critical element because the way of communication between providers and customers is a major part of a service operation as well as a crucial source of innovation (Den Hertog \& Bilderbeek, 1999). The interface includes a service delivery system such as an internal system, which can link service providers to perform well or to provide innovative services. This is not only about empowering staffs but also about making them productive in delivering services/products effectively. Therefore, service innovation in the forms of a new service delivery system, such as social media and the use of technology, can be emphasized as a communication tool between service providers and customers.

Second, one of the main categories identified as a service innovation by private club GMs/COOs and members were "services," representing about $48 \%$ from the GMs/COOs" responses and about $37 \%$ of the members' responses. Compared to manufacturing innovation, 
service innovation is a more intangible and invisible approach to a new idea or an attempt to deal with a problem (Den Hertog \& Bilderbeek, 1999). It also includes the reconstruction of existing service processes and performances in order to keep the organizations' offerings fresh. Although a new idea may not be a totally new way of thinking in business, it can serve as a platform for new offerings in the form of a new trial. As highlighted in other studies about management's attitude toward service innovations (Chan, Go, \& Pine, 1998), managers prefer gradual changes or incremental innovations to radical innovations, which require substantial adjustments in both delivery systems and customer behaviors. This study extends the view by showing that the private club GMs/COOs are trying to incorporate incremental innovations in the form of improved services that not only increase the level of participation among members in club activities and attract new members to the club, but also provide more value to member-owners. In particular, our results showed that improving food and beverage services is a great way to encourage members to visit the club more often and spend more, thereby increasing club revenues. Based on the results, future research could explore how services firms can improve performance by actively engaging customers in their new service initiatives. In the product innovation literature there is much debate about the level of involvement of customers in the innovation process. Some researchers argue that for firms to truly innovate they must stay away from the customers because customers do not know what they want (Brown, 2001; Steve Jobs in Isaacson, 2012, p.97). Others argue that understanding what customers need is the first crucial step in developing a successful innovation (Hauser, Tellis \& Griffin, 2006). However, there is not much research in the service innovation literature about the role of the customer. Research shows customers are co-creators with staff members of the value (Vargo \& Lusch, 2004), which 
indicates that customers will play an integral role in helping firms design new value propositions and delivery methods and systems.

Third, the other main category groups identified by private club GM/COOs and the members were "member engaging activities," "member recruitment," and facility upgrade. Engaging members in the club by offering activities that attract their interest is critical for the survival of the clubs. Additionally, providing membership options that signal value to potential members is a critical, ongoing need. Research shows that the clubs have lost on average one out of ten members due to the economic recession (Brasser, 2011). The Club Managers Association of America (CMAA) also has reported that country clubs have been significantly losing their membership and suffering with financial difficulties (Smith, 2010). Furthermore, O’Donnell (2012) studied the strategies that many club managers are employing in order to recruit new members with the aim of enhancing financial stability. Despite members relatively heavy focus on acknowledging the member recruitment initiatives undertaken by their clubs, we did not see such strength of response from GMs/COOs when asked about initiatives undertaken to introduce new products or services. Potentially managers do not treat member recruitment as part of the product offering but more as a strategy to support the core offerings. Such views can also be attributed to the misunderstanding associated with the word "innovation." Many managers in the service industry do not associate the word innovation with services, they consider that innovation mostly takes place in manufacturing sectors. This is the very reason why more research needs to focus on understanding what innovation means to service firm managers and their customers.

Fourth, our results reflected another discrepancy between GMs'/COOs' and members' focus on innovation. Almost $23 \%$ of the members reported infrastructure upgrades as one of their top innovation experiences, whereas only $10 \%$ of the GMs/COOs reported about such upgrade 
initiatives. Facility upgrades typically require substantial capital investment and this may be the possible reason for a low response rate from the GMs/COOs. However, assessing members' responses points to evidence that any infrastructure improvements made by the clubs seem to impact member experiences very positively. Literature is replete with the proposition that in order to stay competitive in the marketplace, firms must keep their offerings fresh; and for service firms a critical element of such offerings is the physical environment. An interesting direction for future research would be to study whether short-term capital investments in offering innovative facility upgrades provide over time a higher level of returns, or are managers better off by being conservative with capital improvements. It is interesting here to study the different innovative approaches managers have undertaken to find a balance in the use of funds for capital improvement with providing state-of-the-art facilities.

Fifth, the results of this study also show that clubs are moving toward building business propositions that attract more members. For example by enhancing social and family-oriented activities, GMs/COOs are able to influence directly member attraction and retention. This finding also compliments the findings of Frambach, Barkema, Nooteboom, \& Wedel (1998) who discovered that business strategy was one of the most important determinants of successful innovation adoption. They suggested that organizations focus on reducing the risk of innovation adoption by explicitly communicating with staffs and customers for a successful innovation adoption.

Sixth, this study extends the existing literature on the relationship between service providers and customers by showing that the act of caring by staffs and GM/COO improves members' overall experiences at the club. Customers evaluate the quality of service while they are interacting with the staffs who are working in the front of the house, member-contact areas. 
Therefore, successful service innovation depends on the impact of the transformation process between the staffs and customers (Abramovici \& Bancel-Charensol, 2004). In particular, the interface between the service provider and its customers is a critical element because the twoway communication between providers and customers is a major part of each service business and a crucial source of innovation (Den Hertog \& Bilderbeek, 1999). The interface includes a service delivery system such as an internal system, which can link service providers to perform well or to provide innovative services. This is not only about empowering staffs but also about making them productive creators and deliverers of products and services. Therefore, service innovation in the forms of new service delivery systems, such as social media and the use of technology, are growing in importance.

Seventh, the last finding focuses on building emotional connections with members, and tends to suggest that clubs have much to gain by making the members feel more connected with the clubs. Perhaps the best way to begin this journey with members is by providing them with reasons for a quick return, such as by organizing events that bring them back or by offering specials that encourage buying behaviors. The role of relationship marketing is paramount for service organizations. Unfortunately, most of the research in relationship marketing is primarily focused in the business-to-business area. However, the entire service sector has much to gain by adopting relationship marketing practices to better understand customer needs and build stronger relationships. Emotional connections in private clubs are, on the one hand, easier than other service organizations. This ease is related to the on-site, frequently daily presence of club members. Also, some members represent a legacy of membership in their families who have been members of their club for decades. In addition, many clubs have been in existence for 
decades and over a century. This distinctive service organization is steeped in traditions and connections spanning many years.

Relationships among private club members, particularly committee members and boards of directors, are essential for moving the club forward. The members often gain experiences in volunteer leadership as a committee member, then as the chairman of a club committee. In succession, these committee chairs move to membership on the club's board of directors. A smaller number serve as chairman of the board of directors. All of these service opportunities interface with the club's COO or GM; again relationships become a critical component of collaborating and working together.

\section{Future Research and Limitation}

This study had some shortcomings and areas for future refinement. First, this research was a study via a survey, rather than doing in-person interviews. In-person interviews with GMs/COOs and members could allow for gaining more understanding of the process adopted in selecting innovation initiatives, as well as a better understanding of how managers approach and engage members in new service initiatives. Second, although qualitative studies can provide great insights to problems, their generalizability is relatively low until empirical studies can provide support. Future research can build on this study and examine and test empirical models that focus on understanding managerial traits and the roles of co-creation on innovation success, and the resulting firm performance. Since relationship building is a key factor in service environments; future research could explore more deeply the relationship marketing literature to examine innovation synergies. Third, this paper only focused on understanding the member-owned private club industry, so the generalizability of our results is limited. But given these 
private clubs influence the tone for hospitality businesses in that they are relationshipbased not transaction-based interactions between club members and their club, this study may be viewed as the first necessary step in the right direction in terms of understanding customer-firm approaches to service innovation in hospitality service businesses. Fourth, the sample size was mostly dominated by member-owned golf and country clubs that limited our ability to study the differences between club types. Future research can explore if the meaning of innovation differs across club types. Fifth, the online response rate of $17 \%$ may seem to be relatively low. Although there is no clear guideline on the minimum acceptable response rate (Nickson, Warhurst \& Dutton, 2005), future research can focus on replicating the results with a higher response rate.

One of our goals with this project was to ignite the fire for more in-depth research in the field of service innovation, specifically in private clubs and generally in hospitality business. We also hope that our qualitative study will allow managers and researchers alike to have a better understanding of the basic thinking associated with service innovation, and help further develop and refine this thinking to provide useful information for service managers and staffs.

\section{References}

Abramovici, M., \& Bancel-Charensol, L. (2004). How to take customers into consideration in service innovation projects. The Service Industries Journal, 24(1), 56-78.

Alter, S. (2008). Service system fundamentals: Work system, value chain, and life cycle. IBM Systems Journal, 47(1), 71-85.

Barrows, C. W. (1995). A decade of research in club management: A review of the literature in academic journals. Journal of Hospitality \& Leisure Marketing,2(4), 73-92. 
Barrows, C. W. (1999). A definition of clubs, in Jafari, J. (ed.). Encyclopedia of tourism. London: Routledge.

Barrows, C.W., \& Ridout, M. (2010). Another decade of research in club management: A review of the literature in academic journals for the period 1994-2005. Journal of Hospitality Marketing \& Management, 19, 421-463.

Barrows, C. W., \& Walsh, J. (2002). Bridging the gap between hospitality management programs and the private club industry. International Journal of Contemporary Hospitality Management, 14(3), 120-127.

Bettencourt, L. (2010). Service innovation: How to go from customer needs to breakthrough services. McGraw Hill Professional.

Bitner, M. J., Booms, B. H., \& Mohr, L. A. (1994). Critical service encounters: The employee's viewpoint. Journal of Marketing, 58, 95-106.

Bitner, Mary J., Booms, B. H., \& Tetreault, M. S. (1990). The service encounter: Diagnosing favorable and unfavorable incidents, Journal of Marketing, 54 (January), 71-84.

Brasser, R. C. (2011). The value equation of membership. Club Management, 40-41.

Brown, S. (2001). Torment Your Customers (They'll Love It). Harvard Business Review, 79(9), $82-88$

Chae, B. K. (2012). An evolutionary framework for service innovation: Insights of complexity theory for service science. International Journal of Production Economics, 135(2), 813-822.

Chase, R. B., \& Apte, U. M. (2007). A history of research in service operations: What's the big idea?. Journal of Operations Management, 25(2), 375-386. 
Chan, A., Go, F. A., \& Pine, R. (1998). Service innovation in Hong Kong: attitudes and practice. Service Industries Journal, 18(2): 112-124.

Chell, E. (1998), The critical incident technique, in Symon, G. and Cassells, C. (eds). Qualitative Methods and Analysis in Organizational Research (London: Sage): 51-72.

Chesbrough, H., \& Spohrer, J. (2006). A research manifesto for services science. Communications of the ACM, 49(7), 35-40.

Chung, B., \& Hoffman, D. K. (1998). Critical incidents: Service failures that matter most. Cornell Hotel and Restaurant Administration Quarterly, 39(3), 66-71.

Cova, B., \& Salle, R. (2008). Marketing solutions in accordance with the SD logic: Co-creating value with customer network actors. Industrial marketing management, 37(3), 270277.

Den Hertog, P., \& Bilderbeek, R. (1999). Conceptualizing service innovation and service innovation patterns. Thematic essay within the framework of the Research Programme Strategic Information Provision on Innovation and Services (SIID) for the Ministry of Economic Affairs, Directorate for General Technology Policy.

Djellal, F., \& Gallouj, F. (2005). Mapping innovation dynamics in hospitals. Research policy, 34(6), 817-835.

Dotzel, T., Shankar, V., \& Berry, L. L. (2013). Service Innovativeness and Firm Value. Journal of Marketing Research, 50 (April), 259-276.

Elo, S. \& Kyngäs, H. (2008). The qualitative content analysis process. Journal of Advanced Nursing, 62(1), 107-115.

Enz, C. A. (2012). Strategies for the implementation of service innovations. Cornell Hospitality Quarterly, 53(3): 187- 195. 
Enz, C., \& Siguaw, J. (2003). Revisiting the best of the best: Innovations in hotel practice. Cornell Hotel and Restaurant Administration Quarterly, 4(5/6): 115-123.

Ericsson, K. A., \& Simon, H. A. (1980). Verbal reports as data. Psychological Review, 87(May), 215-250.

Essén, A. (2009). The emergence of technology-based service systems: A case study of a telehealth project in Sweden. Journal of Service Management, 20(1), 98-121.

Ferreira, R. R. (1997). An evaluation of private club members' desires in price, food quality and level of service. Journal of Hospitality \& Leisure Marketing, 4(4), 49-62.

Ferreira, R. R., \& Gustafson, C.M. (2014). Impact of economic downturns on Private Club membership levels. Journal of Tourism and Hospitality Management, 2(2), 01-20.

Frambach, R. T., Barkema, H. G., Nooteboom, B., \& Wedel, H. (1998). Adoption of a service innovation in the business market: an empirical test of supply-side variables. Journal of Business Research, 41(2), 161-174.

Gatignon, H., \& Xuereb, J. M. (1997). Strategic orientation of the firm and new product performance. Journal of Marketing Research, 34 (February), 77-90.

Gremler, D. D. (2004). The critical incident technique in service research. Journal of Service Research, 7(1), 65-89.

Gröschl, S. (2012). Employability in hotel operations presumed incapable: Exploring the validity of negative judgments about persons with disabilities and their employability in hotel operations. Cornell Hospitality Quarterly, 54(2), 114-123.

Hendler, F., \& LaTour, K.A. (2008). A qualitative analysis of slot clubs as drivers of casino Loyalty. Cornell Hospitality Quarterly, 49(2), 105-121. 
Hauser, J., Tellis, G. J., \& Griffin, A. (2006). Research on innovation: A review and agenda for Marketing Science. Marketing Science, 25(6), 687-717.

Hertog, P. D. (2000). Knowledge-intensive business services as co-producers of innovation. International Journal of Innovation Management, 4(04), 491-528.

Hjalager, A., \& Konu, H. (2011). Co-Branding and Co-Creation in Wellness Tourism: The Role of Cosmeceuticals. Journal Of Hospitality Marketing \& Management, 20(8), 879-901.

Hu, M.L., Horng, J.S., \& Sun, Y.H.C. (2009). Hospitality teams: Knowledge sharing and service innovation performance. Tourism Management, 30, 41-50.

Huang, C., \& O’Brien, K. M. (2015). The Impacts of Perceived Environmental Uncertainty, Outlook, and Size on Strategic Planning in Private Clubs. Journal of Hospitality Marketing \& Management, 24(5), 554-571.

Hubbard, S. S., \& O’Neill, M. A. (2006). Quality service in clubs. Contemporary Club Management, 317-336.

Isaacson, W. (2012). The real leadership lessons of Steve Jobs. Harvard Business Review, 90(4), 92-100, 102.

Insch, G. S., Moore, J. E., \& Murphy, L. D. (1997). Content analysis in leadership research: Examples, procedures, and suggestions for future use. Leadership Quarterly, 8, 1-24.

Kim, S.H., Cha, J. M., Kim, M. R., Cichy, R.F., \& Tkach. J.K. (2016). Roles of private club volunteer leaders: An exploratory study of content analysis, International Journal of Hospitality and Tourism Administration, 17(1), 43

Kim, D. D., Gilmore, T.L., \& Jolliff, W. A. (2012). Annual industry accounts: Advance statistics on GDP by industry for 2011. U.S. Bureau of Economic Analysis Survey of Current Business, (May), 6-22. 
Knutson, B. J. (2002). Mature club members: Are they a homogeneous or heterogeneous market. Journal of Hospitality \& Leisure Marketing, 9(1-2), 35-51.

Kristensson, P., Matthing, J., \& Johansson, N. (2008). Key strategies for the successful involvement of customers in the co-creation of new technology-based services. International Journal of Service Industry Management,19(4), 474-491.

LaTour, M. (2007). Using new brain science to address the quarterdeck dilemma. Cornell Hospitality Quarterly, 48(3), 345-347.

Lievens, A., \& Moenaert, R.K. (2000). Project Team Communication in Financial Service Innovation. Journal of Management Studies, 37(5),733-766.

Lusch, R. F., Vargo, S. L., \& O’Brien, M. (2007). Competing through service: Insights from service-dominant logic. Journal of retailing, 83(1), 5-18.

Maglio, P. P., \& Spohrer, J. (2008). Fundamentals of service science. Journal of the Academy of Marketing Science, 36(1), 18-20.

Martínez-López, M. A., \& Vargas-Sánchez, A. A. (2013). The Strategic Management Process and the Innovative Capacity of the Spanish Hotel Industry. Journal Of Hospitality Marketing \& Management, 22(6), 596-618.

Nickson, D., Warhurst, C., \& Dutton, E. (2005). The importance of attitude and appearance in the service encounter in retail and hospitality. Managing Service Quality: An International Journal, 15(2), 195-208.

Noble, C. H., \& Mokwa, M. P. (1999). Implementing marketing strategies: Developing and testing a managerial theory. Journal of Marketing, 63(4), 57-73. 
O'Donnell, R. (2012). Membership recruitment in the private club industry. A thesis

Submitted to the Kent State University College of Education, Health, and Human Services

Ottenbacher, M., \& Gnoth, J. (2005). How to develop successful hospitality innovation. Cornell Hotel and Restaurant Administration Quarterly, 46(2), 205-222.

Ottenbacher, M., Gnoth, J., \& Jones, P. (2006). Identifying determinants of success in development of new high-contact services: insights from the hospitality industry. International Journal of Service Industry Management, 17(4), 344-363.

Perdue, J., \& Koenigsfeld, J. (2013). Contemporary Club Management. East Lansing, MI: Educational Institute of the American Hotel \& Lodging Association.

Pullman, M., McGuire, K., \& Cleveland, C. (2005). Let me count the words: Quantifying openended interactions with guests. Cornell Hotel and Restaurant Administration Quarterly, 46(3), 323-343.

Ronan, W. W., \& Latham, G. P. (1974). The reliability and validity of the critical incident technique: A closer look. Studies in Personnel Psychology, 6 (Spring), 53-64.

Sheehan, J. (2006). Understanding service sector innovation. Communications of the $A C M, 49(7), 42-47$.

Smith, A. (2010). Duffers score deals at the club. Kiplinger's Personal Finance, 64(2), 18. Retrieved July 7, 2013 from http://www.kiplinger.com/article/spending/T062C000-S002-duffers-score-deals-at-the-club.html

Spohrer, J. C., \& Maglio, P. P. (2010). Toward a science of service systems. In Handbook of service science (pp. 157-194). Springer US. 
Stepchenkova, S., Kirilenko, A., \& Morrison, A. (2009). Facilitating content analysis in tourism research. Journal of Travel Research, 47(4), 454-469.

Tiger, A., Stamey Jr, J., \& Metts, S. (2010). Service operations management at the golf course: Informaiton technology design choices change golfers' waiting time. Business and Economic Review 13: 62-67.

Vargo, S. L., \& Lusch, R. F. (2004). Evolving to a new dominant logic for marketing. Journal of Marketing, 68(January), 1-17.

Vargo, S. L., \& Lusch, R. F. (2011). It's all B2B... and beyond: Toward a systems perspective of the market. Industrial Marketing Management, 40(2), 181-187.

Verma, R., C. Dixon, A.M., Enz, C., Thompson, G., \& Victorino, L. (2008). Key elements in service innovation: Insights for the hospitality industry. Cornell University Roundtable Proceedings, no. 1 (November). Ithaca, NY.

Victorino, L., Verma, R., Plaschka G., \& Chekitan, D. (2005). Service innovation and customer choices in the hospitality industry. Managing Service Quality, 15(6), 555-576.

Walker, R. H., Craig-Lees, M., Hecker, R., \& Francis, H. (2002). Technology-enabled service delivery: An investigation of reasons affecting customer adoption and rejection. International Journal of Service Industry Management, 13(1), 91-106.

White, D. (2012). Sustainability grows. The Boardroom. May/June, 1.

White, F. M., \& Locke, E. A. (1981). Perceived determinants of high and low productivity in three occupational groups: A critical incident study. Journal of Management Studies, 18(4), 375-387. 
Table 1: Demographics

\begin{tabular}{lcccc}
\hline & \multicolumn{2}{c}{ Manager } & \multicolumn{2}{c}{ Member } \\
\hline $\begin{array}{l}\text { Average Age } \\
\text { Gender }\end{array}$ & \multicolumn{2}{c}{54} & \multicolumn{2}{c}{63} \\
Males & 260 & $86.7 \%$ & 641 & $67.1 \%$ \\
Females & 40 & $13.3 \%$ & 315 & $32.9 \%$ \\
Ethnicity & & & & \\
White & 286 & $95.1 \%$ & 904 & $94.6 \%$ \\
African American & 1 & $0.5 \%$ & 6 & $0.6 \%$ \\
Hispanic & 4 & $1.2 \%$ & 10 & $1.1 \%$ \\
Asian American & 8 & $2.7 \%$ & 25 & $2.6 \%$ \\
Other & 1 & $0.5 \%$ & 11 & $1.2 \%$ \\
Education & 30 & $9.9 \%$ & 470 & $49.1 \%$ \\
A graduate degree & 23 & $7.7 \%$ & 141 & $14.8 \%$ \\
Some graduate school & 155 & $51.6 \%$ & 245 & $25.6 \%$ \\
Four year college degree & 89 & $29.7 \%$ & 90 & $9.4 \%$ \\
Some college & 3 & $1.1 \%$ & 10 & $1.1 \%$ \\
High school graduate & & & & \\
&
\end{tabular}


Exhibit 1

Top Initiatives for Introducing New Services/Products

\begin{tabular}{|c|c|c|c|}
\hline Category & $\begin{array}{l}\text { Number of } \\
\text { Responses }\end{array}$ & $\begin{array}{l}\text { Percentage of } \\
\text { Respondents }\end{array}$ & Qualitative Comments \\
\hline $\begin{array}{l}\text { Services } \\
\begin{array}{l}\text { - Food and Beverage } \\
\text { - Additional Services } \\
\text { - Improved Services }\end{array}\end{array}$ & 144 & $\begin{array}{c}\mathbf{4 8 \%} \\
22 \% \\
17 \% \\
9 \%\end{array}$ & $\begin{array}{l}\text { "Introduced Club Night offering a } \\
\text { value themed dinner buffet with a } \\
\text { discounted guest fee for dinner. Sold } \\
\text { out } 10 \text { of } 10 \text { nights. Revenue growth } \\
\text { of } 500 \% \text { vs. last year in F\&B on } \\
\text { each club night by offering the value } \\
\text { added golf to sell dinner." } \\
\text { "Adding a new deck to club house } \\
\text { and revamping dining menu. F\&B } \\
\text { revenue has increased by } 150 \% \text { from } \\
\text { prior year." } \\
\text { "We offer valued guest days which } \\
\text { include lunch, drink, cart, and greens } \\
\text { fees at a reduced rate. Guest fees and } \\
\text { dining revenues have increased on } \\
\text { our slowest day of the week." }\end{array}$ \\
\hline $\begin{array}{l}\text { Member Engaging } \\
\text { Activities } \\
\text { - } \text { Social Activities } \\
\text { - } \text { Family-Oriented } \\
\text { Activities }\end{array}$ & 60 & $\begin{array}{l}23 \% \\
12 \% \\
11 \%\end{array}$ & $\begin{array}{l}\text { "Young member focused social } \\
\text { events e.g. Havana White Nights, } \\
\text { Summer Solstice. These have been } \\
\text { well attended and have created a } \\
\text { buzz about what is going on at the } \\
\text { club." } \\
\text { "Emphasis on family-oriented } \\
\text { entertainment, Easter, Memorial } \\
\text { Day, Fourth of July, Halloween, } \\
\text { Christmas, adult entertainment with } \\
\text { noted jazz musicians. All high cost } \\
\text { events." }\end{array}$ \\
\hline $\begin{array}{l}\text { Communication } \\
\text { - Social Media } \\
\text { - Use of Technology }\end{array}$ & 45 & $\begin{array}{c}\mathbf{1 5 \%} \\
10 \% \\
5 \%\end{array}$ & $\begin{array}{l}\text { "Facebook. Created publicly } \\
\text { available pictures of events. Results } \\
\text { not yet known." } \\
\text { "Improved our communication } \\
\text { through an interactive website and } \\
\text { online marketing" } \\
\text { "Implementing new software } \\
\text { allowing the members to utilize } \\
\text { online bill paying, drill down }\end{array}$ \\
\hline
\end{tabular}




\begin{tabular}{|c|c|c|c|}
\hline & & & $\begin{array}{l}\text { capability on charge tickets, } \\
\text { paperless transactions in all areas." }\end{array}$ \\
\hline \multirow[t]{2}{*}{ Facility Upgrade } & 30 & $10 \%$ & $\begin{array}{l}\text { "Renovated } 60 \text {-year old kitchen. } \\
\text { Initiative helped increase member } \\
\text { dining usage." }\end{array}$ \\
\hline & & & $\begin{array}{l}\text { "Construction of a dedicated short } \\
\text { game facility. The facility is being } \\
\text { built over an underutilized 5-hole } \\
\text { short course. Use at club for practice } \\
\text { instead of just golf, increased use at } \\
\text { driving range. Drive traffic to the } \\
\text { club in times when it used to be } \\
\text { quiet." }\end{array}$ \\
\hline $\begin{array}{l}\text { Better Management } \\
\text { - Member Survey } \\
\text { - Staffing }\end{array}$ & 12 & $\begin{array}{l}4 \% \\
2 \% \\
2 \%\end{array}$ & $\begin{array}{l}\text { "Extensive membership survey } \\
\text { done." } \\
\text { "Adding key year-round staff to } \\
\text { better prepare for relatively short } \\
\text { season." }\end{array}$ \\
\hline
\end{tabular}


Exhibit 2

Top Innovative Services/Products That Have Improved Member Experience

\begin{tabular}{|c|c|c|c|}
\hline Category & $\begin{array}{l}\text { Number of } \\
\text { Responses }\end{array}$ & $\begin{array}{l}\text { Percentage of } \\
\text { Respondents }\end{array}$ & Qualitative Comments \\
\hline $\begin{aligned} \text { Services } & \\
& \\
\text { - } & \text { Food and } \\
& \text { Beverage } \\
\text { - } & \text { Additional } \\
& \text { Service Features } \\
\text { - } & \text { Friendly and } \\
& \text { Caring Staff }\end{aligned}$ & 359 & $\begin{array}{l}37.55 \% \\
24.85 \% \\
10.70 \%\end{array}$ & $\begin{array}{l}\text { "Reintroduced one of the four } \\
\text { clubhouses under a new food } \\
\text { concept." } \\
\text { "Theming the various restaurants." } \\
\text { "Increasing the variety of dining } \\
\text { options." } \\
\text { "One of the pools is now open year } \\
\text { round which increases our ability to } \\
\text { use the resources." }\end{array}$ \\
\hline $\begin{array}{l}\text { Facility Upgrade } \\
\begin{array}{l}\text { - Renovation } \\
\text { - Fitness Center } \\
\text { - Golf Facilities }\end{array}\end{array}$ & 215 & $\begin{array}{c}\mathbf{2 2 . 4 5 \%} \\
17.26 \% \\
3.19 \%\end{array}$ & $\begin{array}{l}\text { "Greens being installed that will no } \\
\text { longer require reseeding. Excellent } \\
\text { cost consciousness." } \\
\text { "Upgraded golf courses." } \\
\text { "Improved/expanded the fitness } \\
\text { center." }\end{array}$ \\
\hline $\begin{array}{cl}\text { Member Recruitment } \\
\text { - } \\
\text { Membership } \\
\text { Flexibility } \\
\text { - New Member } \\
\text { Initiatives }\end{array}$ & & $\begin{array}{c}\mathbf{2 0 . 3 8 \%} \\
9.31 \%\end{array}$ & $\begin{array}{l}\text { "New membership fees resulting in } \\
\text { more members." } \\
\text { "New membership drive - very } \\
\text { successful." } \\
\text { "Strong effort to attract new } \\
\text { members through innovative } \\
\text { approaches." }\end{array}$ \\
\hline $\begin{array}{l}\text { Member Engaging } \\
\text { Activities } \\
\text { - Additional } \\
\text { Activities } \\
\text { - Youth and Kids } \\
\text { Activities }\end{array}$ & 125 & $\begin{array}{l}\mathbf{1 3 . 1 2 \%} \\
10.00 \% \\
3.12 \%\end{array}$ & $\begin{array}{l}\text { "They sponsor sporting events that } \\
\text { include members and others. Pro } \\
\text { tennis, golf, etc." } \\
\text { "More golf clinics. Keeps costs } \\
\text { down allowing more lessons and } \\
\text { increases enjoyment." } \\
\text { "Wellness lectures with authors." } \\
\text { "More children's programs-- } \\
\text { important to involve more people } \\
\text { and families in coming to the club }\end{array}$ \\
\hline
\end{tabular}




\begin{tabular}{|c|c|c|c|}
\hline & & & and using it." \\
\hline $\begin{array}{l}\text { Improved Perks } \\
\begin{aligned} \text { - } & \text { More Value for } \\
& \text { Money } \\
\text { - } & \text { Guest Packages } \\
\text { - } & \text { Member } \\
& \text { Involvement } \\
\text { - } & \text { Dress Code }\end{aligned}\end{array}$ & 33 & $\begin{array}{l}3.50 \% \\
2.21 \% \\
0.76 \% \\
0.40 \% \\
0.13 \%\end{array}$ & $\begin{array}{l}\text { "TGIF: the golf is free on Fridays } \\
\text { when you dine." } \\
\text { "Created options for guest } \\
\text { packages, which lowers the cost for } \\
\text { frequent guests. I have been able to } \\
\text { invite guests more often." } \\
\text { "Relaxed dress codes for families } \\
\text { with younger children and for those } \\
\text { who desire comfortable informal } \\
\text { dining." }\end{array}$ \\
\hline $\begin{array}{l}\text { Communication } \\
\begin{array}{l}\text { - Use of Technology } \\
\text { - Frequent } \\
\text { Communication }\end{array} \\
\end{array}$ & 29 & $\begin{array}{c}\mathbf{3 . 0 0} \% \\
1.78 \% \\
1.22 \%\end{array}$ & $\begin{array}{l}\text { "App for smart phones and tablets- } \\
\text { make the website easier to use." } \\
\text { "Increase e-mail newsflash that keep } \\
\text { me informed almost immediately." }\end{array}$ \\
\hline
\end{tabular}

